\title{
LEAN-DRIVEN PASSENGER EXPERIENCE DESIGN
}

\author{
Filippo Bosi ${ }^{1}$, Maria Antonietta Esposito², and Rafael Sacks ${ }^{3}$
}

\begin{abstract}
In the contemporary agenda of airport design, good spatial design is fundamental to properly and efficiently manage boarding and disembarking processes. It contributes to the Passenger Experience and social sustainability of the terminal itself. This correlates with higher satisfaction levels from the passenger experience. By contrast, current practices of airport design do not properly cope with its requirements and the subsequent operation phase, because the project is not associated with the complete set of stakeholder requirements including the passengers to systematic modelling and management of their experience. The airport terminal is considered a temporary production system, its focus being the transformation of travellers, aimed to maximize the value for passengers, exploiting information management to better accommodate processes and project structuring. In a lean perspective, the terminal is a "flight factory", whose layout is crucial not only for process efficiency but also to achieve higher performance and user satisfaction, the main metrics for quality service evaluation. Considering the multidisciplinary and complex features involved in airport terminal space programming, Lean Design could have important outcomes in the search for project design integration, effective solutions, quality and all-encompassing sustainability. In this paper we discuss a theoretical framework to investigate value delivery in airport terminal design through the integration of lean thinking, constituting the basis for future research on Passenger Experience.
\end{abstract}

\section{KEYWORDS}

Project Design, Project Design Process, Project Design Management, Organisational Models for Project Design, Lean Design Management.

1 PhD, Università degli Studi di Firenze - Dipartimento di Architettura, Via della Mattonaia, Firenze, 50127, ITA, +39 3280025694, txp.fbo@ gmail.com

2 Professor, Università degli Studi di Firenze - Dipartimento di Architettura, Via della Mattonaia, Firenze, 50127, ITA, +39 3280025694, mariaantonietta.esposito@unifi.it

3 Professor, Israel Institute of Technology - Faculty of Civil and Environmental Engineering, Haifa, Israel, cvsacks@technion.ac.il 


\section{INTRODUCTION}

This exploratory paper investigates the current challenges of airport terminal design and Passenger Experience design, and discusses the transfer of Lean process logic to airport terminal project development. It also discusses the potential benefits of strengthening Lean knowledge for airport industry project participants with respect to passenger experience design. We argue that implementing Lean principles in design drivers for Passenger Experience improves travel quality perception and reduces the perceived travel cost for the passengers.

The work is part of a broader research dealing with Lean design methodologies and tools for integrating the service cycle in airport design. The foundational elements of the research are the common practices of airport design (Odoni and de Neufville, 1992; Esposito, 2010; IATA, 2014) and the literature dealing with design process, airport terminal design, Lean Design, and Lean design integration in design process management (Bosi, 2016). The literature review suggests that airport design project participants rely on obsolete matrices for their design process, unable to provide consistent project information and therefore develop a project responding to the requirements. We assume that this is caused by the complexity of design for the aviation industry and the fast pace of requirements changes, both due to regulations and market evolution (De Neufville and Scholtes, 2011). Elements drawn from literature suggest a research gap in the implementation of Lean thinking at the inception of airport terminal projects. This is discussed with a literature review, drawing useful elements to describe a research gap in common design practices for the aviation industry and identifying Lean Passenger Experience design drivers that foster a "Lean Consumption" of the time spent in the terminal.

The field of investigation is limited to scientific and industrial problems connected to project design development, management and design activities for airport infrastructure development. The application of Lean/product development principles in the aviation industry is still at an initial stage of development and the available literature is limited. Therefore, the research group considered it necessary to start investigating methodological and process aspects bound to project design management.

\section{AGENDA AND CHALLENGES OF CONTEMPORARY AIRPORT TERMINAL DESIGN}

Capacity and Quality of Service challenges for the aviation industry originate from the evolution of regulations and growth in traffic demand, leading to an increased project importance. The choice of the aviation industry as a reference field comes from the complexity of design and operation requirements, the high degree of standardization of projects, multi-disciplinarity of project participants and the foreseen growth of the industry in the future, due to the constant need for fast connections throughout the world. The performances of the project and of the infrastructure are measured by Levels of Service (LOS) (Bosi and Esposito, 2014), which are also paralleled by the various business processes that run inside the terminal. The current models of Airport Terminal 
Design (ATD) are bound to obsolete design matrices that lack flexibility and processfocused features (De Neufville and Scholtes, 2011; Shuchi et al., 2012), with the biggest shortcomings found in project development and delivery processes (QUT, 2012; Shuchi et al., 2012). These are seen as stacks of activities that generate finished products, instead of transforming project information. In the end the industry is capable of delivering quality to airport management companies (its clients), but with scarce coordination within the design process. Also, Project Information (PI) provision and PI management in the life cycle of the airport - critical for Operation \& Maintenance - is usually not associated with systematic modelling and standards, resulting in the impossibility to cope with the changes occurring in operations, services and requirements over time (QUT, 2012; Shuchi et al., 2012).

The end-users of most airport services are the airline carriers and passengers/visitors. Project design success is evaluated in airports using several parameters related to different stakeholders' criteria: direct users as passengers through perception, represented by the comprehensive concept of Passenger Experience, and carriers represented by the processing efficiency in term of time and airport fares. To manage such services, efficient and process-oriented space design is needed by the airport owners to carry on the "productive processes" (boarding and disembarking of passengers and cargo, plus ancillary services) within the passenger infrastructure. Accessible services and clear paths for every user category are necessary to properly conduct all activities, therefore the focus of project participants should be on rationalizing the spaces and their use (Odoni and de Neufville, 1992; de Neufville, 2002; Esposito, 2010). These aspects are key in contributing to quality of service, the other aspect featured in the European Union policies as targets for 2030 (EU: European Commission, 2011A and 2011B), that associate terminal design to performance objectives of the infrastructure, because the allocation of flight slots is based on airport efficiency assessments. An inefficient terminal means reduction of the airport capacity: quality and capacity are deeply intertwined in the aviation industry ground infrastructures.

\section{AIRPORT TERMINAL DESIGN AND PASSENGER EXPERIENCE}

Passenger terminal design generates the bottlenecks and jams that passengers experience within the infrastructure (Jim and Chang, 1998) and airport owners struggle to satisfy their user requirements. Struggles are often caused by an incomplete understanding of requirements and needs (Asher, 1989; Arif et al. 2013). As consumers are disconnected by service providers (Womack and Jones 2005), there is a gap between airport management companies and the travellers. Despite the airport terminals providing space and services, passengers cope with high levels of stress because of the frustration caused by wait times, signage mis-directions, and anxiety during queues (Snowdon et al., 1998; de Neufville, 2002; Womack \& Jones, 2005; De Barros et al., 2007). Striving for improvement is necessary to deal with service quality and passenger experience issues, updating and refreshing at the same time the design paradigms meant to introduce sustainability in the design of terminal infrastructures (Esposito and Macchi, 2012). 
Focusing the design of the terminal on perception of time and space, passengers' physical and psychological needs, space and crowd behaviour contributes to incorporating passenger experience sensitivity in design, avoiding possible "tunnel vision" of project participants on an aircraft-centered process and evolving to a passenger-centered methodology (Ariffin and Yahaya, 2013; Caves and Pickard, 2001; Paleari et al., 2010; Popovic et al., 2009; ACRP, 2011; De Barros et al., 2007; Ciolfi et al., 2012). This provides spatial comfort, service volumes and traffic conditions in the terminal premises, expressed in terms of Levels of Service (LOS). LOS link the final user needs with the airport terminal project, serving both as input and output of the design process itself. These represent the optimal compromise between traffic requirements, operational flexibility, owner specifications, community, passenger needs and also development investments (Ashford, 1988; IATA, 2014). LOS can be considered a "lean" concept or an extension of the Lean mind-set under a certain light, since the optimal LOS represents the best balance between investments (resource), space allotment (resource) and enhancement of the Passenger Experience (value).

\section{PASSENGER EXPERIENCE DESIGN DRIVERS AND CRITERIA}

In the presented research framework, the passenger is the consumer for the service provided by the terminal and the airport management company. Passenger Experience is the consumed product, combined result of the airport project and the ancillary business processes (Bosi, 2016) ongoing in its premises. Passenger Experience within airport terminals is generally regulated by many parameters. Avoiding level changes, making pathfinding clear, and ensuring terminal layout linearity are key factors in conveying a quality travel experience (Esposito, 2010; IATA, 2014). Terminal projects are oriented on the following drivers (Kronenburg, 2007; Esposito, 2010; de Neufville and Scholtes, 2011; Shuchi et al., 2012; Pitsiava-Latinopoulos and Iordanopoulos, 2012; IATA, 2014):

- Optimization of passenger flows. Passengers are introduced to a linear and centralized path with limited forks and level changes. This is a time saving strategy that helps to foster calm and serenity and mitigate travel stress.

- Levels of Service enhancement. Operation and services areas of the terminal are evaluated in the design phase to reach the optimal compromise between resource consumption, investments, perceived quality and allocated space for the given function (IATA, 2014).

- Architectural features. The passenger route must be characterized by a consistent language and coherent architectural choices, to avoid the sense of loss (Snowdon et al., 1998) usually conveyed by travel terminals.

These drivers lead to a process in which different terminal layout options are generated with the goal of optimizing passenger experience. Another strong input for design options are the passengers themselves and their choices: the general rule is that the passenger will always choose routes and services based on his/her travel cost - in addition to the already funded concept of travel time. The result of his or her decisions and how 
such decisions affect design determine a scenario where no passenger can further reduce the time spent on a given route or cannot choose a different path. Many variables define this scenario: time, crowding of hallways, route length, services and attraction points along the route, distance of rest areas and stopping spaces. The passengers, trying to minimize travel time and cost (their resources) within the terminal, will make choices according to their own subjective variables. The variables include the current level of stress - which peaks at security controls - and ease of orientation while moving. The direct consequence of an optimal layout tailored for the passengers is the reduction of disorientation and uncertainty, therefore variability, of passenger experience and perception of spaces.

Maximization of value and minimization of waste and resource consumption are at the core of a Lean mind-set (Lander and Liker, 2007): in its application to the aviation industry, Lean Design must aim for mitigation of project non-compliance to requirements with a dynamic and adjustable management of project flexibility and structuring. In the presented research context, Lean Design fosters the idea that the project is intended as a process whose focus is on the management of the embarking/disembarking process. The terminal project organization becomes a temporary production system, whose outcome the terminal project - is in fact a "prototype", part of the architectural process and precedent to construction. While in serialized production the factory is uniform and the environment is stable (Hicketier et al., 2013), the project organization is a temporary environment with changing structure according to immediate needs. The application of a Lean mind-set, Lean Principles and Lean Design methodologies addresses the need of a production system that maximises project quality, minimizes waste of resources, time, and effort (Aapaoja and Haapasalo, 2014) while aiming to maintain project flexibility (Shuchi et al., 2012) to pursue satisfaction in passenger experience.

\section{IMPLEMENTING LEAN IN TERMINAL DESIGN}

Terminal design is not supported properly by traditional design methodologies (de Neufville and Scholtes, 2011; Shuchi et al., 2012; QUT, 2012), mostly because of its complex and evolutionary nature, highly dependent upon market variations. Design methodologies based only on standard requirements, over-rationalistic and structured sequentially, cannot cope with the evolution of airport design requirements over time. In addition, the final users of the terminal are not properly considered during terminal project development, since the intrinsic features of an airport terminal project are not the same as traditional projects and exceed the usual teamwork boundaries (Wu and Mengersen, 2013). Industry stakeholders have differing project objectives, although they should share consensus on a critical factor: passenger processing improvement not only in terms of space availability - as is often done following traditional design matrices - but also of optimization of operations.

Table 1 outlines the differences between common practice and the proposed Lean Terminal Design paradigm. The table clarifies the proposed concept of Lean-driven terminal design with a focus on operation and flow, which is the primary research contribution. Remodelling consumption of passenger experience at its roots - the terminal 
project - should follow the guidelines of Lean consumption, identified by Womack and Jones (2005) and adapted for the presented scenario:

- Lower the travellers' anxiety curve by providing efficient and stress-free passenger processing;

- Do not waste passengers' time - incoherent signage and wayfinding, path loops, excessive level changes;

- Tailor the services on the passengers' needs and requirements, placing them in appropriate locations along the processing chain (passenger route);

- Provide aggregated services in passenger areas to reduce the passengers' hassle.

Implementing Lean principles in Passenger Experience design also implies re-evaluating the design drivers under the People, Process and Technology pillars of the Lean mind-set. Noticeable Lean design drivers are identified for this scope are (Bosi, 2016):

- Maximizing the contribution of technology for the process, fostering advanced facility management and operation models;

- Optimization of Levels of Service, maximizing processing capacity in the allocated space and with determined resources;

- Linearity and suitable length of paths according to provided facilities and services;

- Coordinated design of dwelling and queuing areas to avoid interferences;

- Dedicated paths for different categories of users, without being discriminatory;

- Guarantee of a minimum LOS in case of airport service disruption, to improve the terminal's social sustainability in any circumstance.

These design drivers establish a connection between the project and Passenger Experience Delivery, implying a shared consensus on the terminal space layout. They subtend a stochastic equilibrium within the terminal facility because, given the passenger and business processes ongoing in the terminal environment, it is not possible to have the same degree of information for every driver. For example, passengers will choose the route that minimizes his perceived travel resource consumption (travel time, energies, etc.); aligning this perception influenced by many random variables to one deterministic and controllable quantity is the aim of Lean-driven Passenger Experience Design. The goal is managing information and reducing the perceived travel cost through the project. This can be achieved through different measures aimed at reaching an "Involuntary System Optimum", e.g. improving pathfinding, Levels of Service, utilizing new technologies such as location-based apps, virtual assistants, customized messaging, information beacons that communicate with passengers' devices while collecting passenger and visitor metrics, fundamental for adjusting the ongoing processes. 
Table 1. Comparison of common airport operation design practices and Lean terminal operation design

\begin{tabular}{|c|c|c|}
\hline Design Aspect & $\begin{array}{c}\text { Common Airport Design } \\
\text { Practices }\end{array}$ & Lean Terminal Design \\
\hline Design priority & $\begin{array}{l}\text { Satisfying traffic/capacity } \\
\text { demand }\end{array}$ & $\begin{array}{c}\text { Design flexibility and perception } \\
\text { of service quality }\end{array}$ \\
\hline Scope & Space program optimization & $\begin{array}{c}\text { Passenger Experience } \\
\text { optimization }\end{array}$ \\
\hline Main evaluation metric & $\begin{array}{c}\text { Processing capacity of the } \\
\text { terminal }\end{array}$ & $\begin{array}{l}\text { Perception of infrastructure by } \\
\text { users, passenger experience }\end{array}$ \\
\hline Design goal & Passenger processing activities & Passenger processing flow \\
\hline $\begin{array}{l}\text { Project management } \\
\text { focus }\end{array}$ & Project delivery & $\begin{array}{l}\text { Management of project } \\
\text { information during the service } \\
\text { life }\end{array}$ \\
\hline Technology integration & $\begin{array}{l}\text { Technology integration in } \\
\text { operation is functional to } \\
\text { improve operations efficiency }\end{array}$ & $\begin{array}{l}\text { Technology integration in } \\
\text { operation is functional to } \\
\text { improve Passenger Experience }\end{array}$ \\
\hline Functional priority & $\begin{array}{l}\text { Controlling environment: } \\
\text { pyramidal hierarchy of operation } \\
\text { over business processes }\end{array}$ & $\begin{array}{l}\text { Integrated environment: parallel } \\
\text { ongoing operations and } \\
\text { business processes }\end{array}$ \\
\hline Design driver & $\begin{array}{l}\text { Operation design is driven by } \\
\text { the terminal project }\end{array}$ & $\begin{array}{l}\text { Operations and passenger } \\
\text { processing is a driver for } \\
\text { terminal design }\end{array}$ \\
\hline $\begin{array}{l}\text { Terminal function over } \\
\text { time }\end{array}$ & $\begin{array}{l}\text { Operations change in time } \\
\text { according to the evolution of the } \\
\text { terminal space program }\end{array}$ & $\begin{array}{c}\text { The space program and } \\
\text { terminal operations' evolution is } \\
\text { intertwined }\end{array}$ \\
\hline Process planning & $\begin{array}{l}\text { Process planning does not allow } \\
\text { variability and adaptability }\end{array}$ & $\begin{array}{l}\text { Process planning has a margin } \\
\text { of variability and adaptability }\end{array}$ \\
\hline
\end{tabular}

\section{CONCLUSIONS}

Integrating Lean principles in passenger experience design results in an innovative design philosophy not only of spaces but also of services for project design teams, whose priorities and targets have a deep connection to passengers' behaviour and their perception of the infrastructure. Implementing Lean consumption principles can enhance Passenger Experience, avoiding misplaced activities and amenities in passenger processing. It allows airport owners to use the information generated in the design phase to optimize the Operation \& Maintenance phase of the building, aiming to improve passenger services. Information obtained from targeted analysis is used for quickresponse problem solving, defining technical, formal and spatial solutions that meet evolving project requirements and passenger expectations. Methodologies originating from this theory could be tested in airport project case studies that have to deal with the 
development of a new terminal project, creating a passenger experience from scratch, or extension of existing airport terminals, confronting the challenge of design to avoid disruption of the Passenger Experience during the construction phases.

The target audience for Lean integration in terminal design practices are stakeholders and project participants from the civil aviation industry, in addition to managers and project teams interested in in airport design methodologies and design verification. Airport owners are the direct beneficiaries of Lean implementation aimed at design and operation flexibility, with airlines and passengers (intended as final users) being indirect beneficiaries. In general, the entire terminal design chain draws benefits from Lean. Scholars and academia in general can further research on the grey fields suggested by this paper, fostering the diffusion of Lean knowledge in the industry along with the integration of Lean in the entire building life cycle.

\section{REFERENCES}

Aapaoja, A. \& Haapasalo, H. (2014). "The Challenges of Standardization of Products and Processes in Construction." Proc. of the 22nd Ann. Conf. of the Int'l Group for Lean Construction. Oslo, Norway.

ACRP (Airport Cooperative Research Program). (2011). "Passenger Level of Service and Spatial Planning for Airport Terminals." ACRP Transportation Research Board Report 55. Washington D.C., ACRP, 2011.

Arif, M., Gupta, A., Williams A. (2013). "Customer service in the aviation industry - An exploratory analysis of UAE airports." Journal of Air Transport Management 32, 1-7.

Ariffin, A. and Yahaya, M. (2013). "The relationship between airport image, national identity and passengers delight: A case study of the Malaysian low cost carrier terminal (LCCT)." Journal of Air Transport Management 31, 33-36.

Asher, M. (1989). "Measuring Customer Satisfaction." The TQM Magazine, 1(2), https://doi.org/10.1108/EUM0000000002995

Ashford, N. (1988). "Level of service design concept for airport passenger terminals - a European view." Transportation Planning and Technology, 12(1), 5-21.

Bosi, F. (2016). Airport Lean Integration, PhD Dissertation, Università degli Studi di Firenze and Technion - Israel Institute of Technology

Bosi, F., and Esposito, M. A. (2014). Achieving Lean Project Design Delivery. In: Esposito M.A., Ciribini A., Dell'Osso G., Daniotti, B., Carbonari, A., Alaimo G. (2014). Energy, Sustainability and Building Information Modeling and Management, Milano: Maggioli, pp. 217-235.

Caves, R.E., and Pickard C.D. (2001). "The satisfaction of human needs in airport passenger terminals." Transport 147(1), 9-15.

Ciolfi, L., Deshpande P. and Bannon L.J. (2012). Understanding Place as Experience: Augmenting Human Activities in Context. In Giaccardi E. (2012) Heritage Matters: Understanding and Experiencing Heritage Through Social Media, London: Routledge, pp. 69-86. 
De Barros, A.G., Somasundaraswaran K., Wirasinghe S. (2007). "Evaluation of level of service for transfer passengers at airports." Journal of Air Transport Management 13(5), 293-298.

de Neufville R. (2002). "Optimal configuration of airport passenger buildings for travelers." Journal of Transportation Research 128:3(211), 1-26.

de Neufville, R. and S. Scholtes (2011). Flexibility in Engineering Design, Cambridge, Massachusetts, MIT Press

Esposito, M.A. (2010). Tecnologie di progetto per il terminal aeroportuale, Firenze, FUP - Firenze University Press.

Esposito, M.A., and Macchi, I. (2012). Low Carbon Airport projects development using the Design Gap Risk Threshold approach. International Journal of Design Sciences and Technology 19(1), 45-62.

European Union: European Commission (2011a). Airport policy in the European Union addressing capacity and quality to promote growth, connectivity and sustainable Mobility, December 1st 2011, COM 823 final.

European Union: European Commission (2011b). Roadmap to a Single European Transport Area - Towards a competitive and resource efficient transport system, March 28th 2011, COM 144 final.

Hickethier, G., Tommelein, I.D. and Lostuvali, B. (2013) "Social Network Analysis of Information Flow in an IPD-Project." Proc. of the 21th Ann. Conf. of the Int'l Group for Lean Construction. Fortaleza, Brazil.

IATA (International Air Transport Association). (2014). Airport Development Reference Manual, 10th edition. Montréal: IATA 2014.

Jim, H. K., Chang, Z. Y., (1998). "An airport passenger terminal simulator: A planning and design tool". Simulation Practice and Theory 6(4), 387-396.

Kronenburg, R. (2007). Flexible Architecture that Responds to Change. London: Laurence King Publishing Ltd.

Lander, E., and Liker, J. K. (2007). "The Toyota Production System and art: making highly customized and creative products the Toyota way." International Journal of Production Research, (45)16, 3681-3698.

Odoni, A.R., and de Neufville, R. (1992). "Passenger terminal design." Transportation Research Part A: Policy and Practice, 26(1), 27-35.

Paleari S., Redondi R., Malighetti P., (2010). "A comparative study of airport connectivity in China, Europe and US: Which network provides the best service to passengers?" Transportation Research Part E: Logistics and Transportation Review, 46(2), 198-210.

Pitsiava-Latinopoulou, M., and Iordanopoulos, P. (2012). "Intermodal Passengers Terminals: Design standards for better level of service." Procedia - Social and Behavioral Sciences 48, 3297-3306

Popovic V., Kraal B., Kirk P., (2009). "Passenger experience in an airport: an activitycentred approach." Proc. of the IASDR Conference 2009, Korean Society of Design Science, COEX, Seoul, 1-10. 
QUT - Queensland University of Technology (2012). Project Airports of the Future, Research report, Queensland University of Technology, < https://research.qut.edu.au/aotf/> (Feb 17, 2018).

Shuchi, S., Drogemuller, R., Kleinschmidt, T. (2012). "Flexible airport terminal design: towards a framework." Proc. of the IIE Asian Conference 2012, Department of Industrial \& Systems Engineering, NUS, Furama Riverfront Hotel, Singapore, 348356.

Snowdon, J.L., El-Taji, S., Montevecchi, M., MacNair, E.A., Callery, C.A., \& Miller, S.E. (1998). "Avoiding the Blues for Airline Travelers". Proc. of the 1998 Winter Simulation Conference. Washington, D.C., U.S.A.

Womack, J. P., and Jones, D. T. (2005). Lean solutions: How companies and customers can create value and wealth together, Free Press, New York, NY.

Wu, P.P.Y. and Mengersen, K. (2013). "A review of models and model usage scenarios for an airport complex system." Transportation Research Part A: Policy and Practice (47), 124-140. 